\title{
Tatar Türkleri Arasındaki Hıristiyanlar: Kreşinler
}

DURMUS ARIK

DOÇ. DR., ANKARA Ü. İLAHIYAT FAKÜLTESI

e-mail: arik@divinity.ankara.edu.tr

\begin{abstract}
Christians among Tatar Turks: Kryashens. Tsarist Russia, from the middle of the 16th to the early in 20 th century, applied policies of Russification and Christianization to the non-Russian nations living in the area of Volga-Ural region. Due to this policies, beside Finno-Ugrians (Mari, Mordvins, and Udmurts), some groups of Chuvashes and Tatars converted to Christianity and Russified. To the present day, the evaluations about the Kryashens showed that they converted to Christianity by the result of this policies. Therefore, they have been considered "Christianized Tatars". The present paper aims to deal with the relations of Kryashens with Tatars, and their situations among Tatars according to researchs and observations made by the author in July and August of 2008 in Tatarstan. Furthermore, this paper gives place to the evaluations of some Kryashens' intellectuals about themself from ethnic and cultural point of view.
\end{abstract}

key words

Tatar Turks, Christianity, Kryashens, Christian Turkish Community

\section{Giriş}

İdil boyu, Türk tarihinin önemli ve ilginç olaylarına sahne olmuştur. İlk Türk İslam devleti olarak kabul edilen İdil Bulgar Devleti bu bölgede kurulmuştur. Daha sonra Altınordu, Kazan Hanlığı başta olmak üzere diğer bazı Türk Hanlıkları da bölge tarihinde yerini almıştır. Bu bölgenin tarihinde Fin Kavimleri ve Ruslar da rol üstlenmiştir. İdil Bulgar Devleti, Altınordu ve daha sonra Kazan Hanlığı bünyesinde Mari, Mordvin, Udmurt gibi Fin kavimleri de yaşamıştır. Ruslar, iki asır boyunca Altınordu'ya vergi ödemiş ve bu kavimler bölgedeki Türk kültüründen etkilenmiştir. Hatta zaman içinde bölgede Türk İslam kültürünün önemli ve güçlü temsilcisi sayılan Tatarların tesiriyle Tatarlaşan- 
lar hiç de az olmamıştır. Tatarlaşanlar arasında Mari, Mordvin, Udmurt gibi Fin kavimleri yanında Ruslar da bulunmuştur. Asırlar boyu Tatar Türkçesi bölgede kullanılan egemen dil olduğundan, söz konusu bu toplulukların hemen hepsi, bölgenin Rus egemenliğine geçişine kadar, Tatar dilini öğrenmiş, ortak dil olarak Tatar Türkçesinde konuşmak suretiyle anlaşabilmiş, hatta kültürel anlamda Tatar/İslam kültürünün etkisinde kalmışlardır.

Türk tarihinin en hazin dönemlerinden biri İdil boyunun ve Kazan Hanl1ğı'nın 16. yüzyılda Rus işgaline uğramasıyla başlamıştır. Korkunç İvan olarak da bilinen Çar İvan Grozniy, Rusya'nın doğusuna, deyim yerindeyse adeta bir "Ortodoks Haçlı Seferi” başlatmış, ele geçirdiği topraklarda yaşayan, Rusça inorodets olarak nitelendirilen gayri Rus unsurları Ruslaştırmak ve Hıristiyanlaştırmak istemiş, bu girişimlerinde Kiliseye de önemli görevler yüklemiştir.

Rus işgaliyle birlikte, ekonomik baskılar, zorba metotlar ve her türlü yıldırma politikalarına başvurmak suretiyle gayri Rus (inorodets) unsurların Hıristiyanlaşması için büyük gayretler sarf edilmiştir. Kazan Hanlığında yaşayan Fin kavimleri; Mariler, Udmurtlar, Mordvinler yanında İdil Bulgarlarının torunları olan Çuvaşlar ve Tatarlar da Çarlık Rus yönetiminin hedefi olmuştur. ${ }^{1}$ Tarihi süreçte söz konusu bu topluluklar arasında belli ölçüde Hıristiyanlığın yayılması sağlanmıştır. İlk sistemli Hıristiyanlaştırma faaliyetleri Tatarlar üzerinde gerçekleştirilmiş, daha sonra uygulanan metotlar diğer gayri Rus unsurları da kapsamışır. Özellikle 19. yüzyılda gayri Rus unsurlar arasında Hıristiyanlığın yayılmasında N.İ. Il'minski'nin ve onun çalışma arkadaşlarının büyük rolü olmuştur. ${ }^{2}$ Hıristiyanlığın yayılmasında daha çok baskı içeren yöntemlere başvurulduğu için istenen düzeyde başarı sağlanamamıştır. Gayri Rus unsurların Hıristiyanlığa karşı tutumunu tasvir eden araştırmacılar ve Rus din adamları çoğu zaman onların iyi birer Hıristiyan olmadığından, onların Hıristiyanlık düzeyi ve anlayışının yüzeysel ve göstermelik olduğundan şikayet etmişlerdir.

Gayri Rus unsurların, Hıristiyanlığı özümseyemediklerinden, baskılarla ya da çeşitli özendirici imkanlara kavuşmak amacıyla onlardan vaftiz olanlar, ilk fırsatta eski inançlarına geri dönmüşlerdir. 19. yüzyıl ve 20. başları bu dönüşlere oldukça fazla sahne olmuştur. Yine de Çarlık Rus yönetimi ve Or-

1 İdil-Ural bölgesinde Türk topluluklarına yönelik eritme faaliyetleri ile ilgili bkz. E.A. Mojarovskiy, İzlojenie hoda missionerskogo dela po prosveşçeniyuyu Kazanskih inorodtsev s 1552 po 1867 gg, Moskova 1880, 5; N.M. Matorin, Religiya u narodov Vol'jsko-Kamskogo kraya, Moskova 1929, 13; Azade A. Rorlich, Volga Tatarları, İstanbul 2000, 87-105; Paul W. Werth, At the Margins of Orthodoxy, Mission, Governance, and Confessional Politics in Russia's Volga-Kama Region, Ithaca and London 2002.

2 V.A. Gorohov,Reaksionnaya şkola politika Çarizma v otnoşenii Tatar Povol'ja, Kazan 1941;F. Efirov, Neruskiye şkolı Povolja, Priuralya i Sibiri, Moskova 1948; 11-17; I. T. Kreindler, Educational Policies Toward Eastern Nationalities in Tsarist Russia, Columbia 1969. 
todoks Kilisesi Hıristiyanlığın yayılmasında başarı sağlamış, Hıristiyanlığa gayri Rus unsurlar arasında yer açmıştır. Bölgede yaşayan Mari, Mordvin, Udmurt ve Çuvaşlar arasında Hıristiyanlık yayılmıştır. Tatarlar arasında da planlı, programlı ve 1srarlı bir biçimde Hıristiyanlaştırma faaliyetleri sürdürülmüş, sonuçta "Kreşin Tatarları" adıyla literatüre geçmiş olan Hıristiyan Tatar gurubu oluşmuştur.

Kreşin sözü kelime olarak; Rusça'da "vaftizli" ya da vaftiz edilmiş" anlamlarına gelmektedir. Bu söz İdil-Ural bölgesinde yalnızca Tatar Türkçesinde konuşan Hıristiyanları ifade etmek için değil, aynı zamanda bölge sakinlerinden vaftiz olmuş, Hıristiyanlaşmış Çuvaşlar ile Mari, Mordvin ve Umdurt gibi Fin kavimleri için de kullanılmıştır. Bu bağlamda genel olarak Kreşin sözüyle baskının da içinde yer aldığ çeşitli metotlara başvurularak yüzeysel biçimde sonradan Hıristiyanlaşan, Hıristiyanlık anlayışı vaftiz olmanın ötesine geçmeyen kimseler ve guruplar kastedilmektedir. İdil-Ural bölgesinde "Tatar" adı etnik bir kimliği ifade ediyor olmakla birlikte, Tatarlar dini bakımdan İslam'ın bölgedeki güçlü temsilcileri olarak da görülmektedir. Bu yüzden "Kreşin Tatarları" şekliyle "Kreşin" sözü ve "Tatar" adının yan yana kullanılması Kreşinler tarafından pek hoş karşılanmamaktadır. Çünkü bu kullanım şekli tarihi süreçte Kreşinlerin İslam'la ilgisi bulunduğu çağrışımını yapmakta, bu da Kreşinlerin Hıristiyanlıkla ilgisinin ve ilişkisinin sorgulanmasına zemin oluşturmaktadır. Bunun da ötesinde Kreşinlerin sahip olduğu bütün kültürel özelliklerin diğer Tatarlarla büyük oranda ortaklığı, onların diğer Müslüman Tatarlarla, tarihin belli dönemlerinde aynı etnik ve dini şemsiyenin altında yer aldığı görüşünü desteklemekte, dolayısıyla bu konu Müslüman Tatarlarla Kreşinler arasında tartışmalara yol açmaktadır. Bu bağlamda Tatarlar onları, kendileriyle aynı etnik kökene sahip olan ancak Rusların Hıristiyanlaştırma politikaları neticesinde vaftiz edilen Tatarlar olduklarını ileri sürerken Kreşinler, kendilerinin Tatarlardan farklı, ancak Türk kökenli bir etnik gurup olduklarını, atalarının İslam'dan ayrılarak Rus politikaları neticesinde Hıristiyanlığı seçtiği şeklindeki iddiaların doğru olmadığını, Hıristiyanlığın onlar arasındaki tarihinin İdil Bulgar Devleti dönemine kadar geri gittiğini iddia etmektedirler. Günümüzde Rus yönetimi ve Kilise de bu ikinci görüşü desteklemekte, Kreşinlerin Tatarlardan ayrı bir etnik gurup olarak tanınmasına destek vermektedir. ${ }^{3}$

Kreşinler, günümüzde çoğunluğu Tataristan Özerk Cumhuriyetinde olmak üzere komşu Cumhuriyetlerde varlıklarını sürdürmektedir. Sayıları hak-

3 Kreşinlerin kimliği ve dini inanışları hakkındaki bazı değerlendirmeler için bkz. Durmuş Arık, "Türk Kültürünün Farklı Bir Boyutu Olarak Kreşin-Hıristiyan Tatarların Dini İnanışları," A.Ü.I..F. Dergisi, Ankara: Ankara Üniversitesi Basımevi, 2007, Cilt: 47, Sayı:1, Yıl: 2006, s. 67-86. 
kında sağlıklı bir rakam verilememekte birlikte, en son 2002 yılında yapılan sayımlarda Kreşin olarak resmi belgelere kaydedilenlerin sayısının 25 bin olduğu, ancak gerçek sayının 250-300 bin civarında olabileceği araştırmacılar ve bazı bilim adamlarınca ifade edilmektedir. Sayının bu kadar yüksek gösterilmesi/gösterilmeye çalışılması Tataristan'da, Tatar nüfus oranındaki üstünlüğ̈̈n Tatarlar aleyhine bozulmaya çalışılması olarak değerlendirilmektedir.

Kreşinler, gelenek, görenek ve kültürlerine bağlılıklarını sürdürmekte, kültürel anlamda Tatarlarla büyük oranda ortaklıklara sahip bulunmaktadırlar. Hatta Kreşin entelektüeli, kendi eski örf, adet, gelenek ve göreneklerini Müslüman Tatarlara göre daha iyi muhafaza ettiklerini iddia etmektedirler. Kazan'da 16. yüzyılda yapıldığı bilinen Tikhvin kilisesi Kreşinlerin ibadetlerini yerine getirdikleri mabetlerden biridir. Kreşin kiliselerinde kendi içlerinden yetişen papazlar görev yapmakta ve kendi dillerinde ibadetlerini gerçekleştirmektedirler. Rus papazların görev yaptığı kiliselere ise Kreşinlerin gereken ilgiyi göstermediklerine dikkat çekilmektedir. Buna rağmen Ortodoks Kilisesinin çeşitli eğitim kurumlarında Rus papazlardan Tatar Türkçesini öğrenip, Kreşinlerin yerleşim birimlerinde bulunan kiliselerde hizmet edecek, Kreşinleri kiliseye çekecek, onların Hıristiyanlık bilincini güçlendirecek papazların hazırlanmasına önem verilmektedir.

Bu yazı, 2008 yılında Temmuz-Ağustos aylarında TíKA desteğiyle Tataristan'da Kreşinler üzerinde yaptı̆̆ımız araştırmanın bir bölümü olarak kaleme alınmıştır. Yazıda, Sovyetler Birliği'nin dağılmasından sonra ortaya çıkan yeni yapılanmada Rusya Federasyonu'nda Tataristan Özerk Cumhuriyeti'nde, doğrudan yerinde yapılan gözlem ve araştırmalara dayalı bilgilerle Kreşinlerin diğer Tatarlar arasındaki konumu ve onlarla ilişkileri sunulmaya gayret edilmiş, ayrıca Kreşinlerin önde gelen entelektüellerinin hem etnik hem de kültürel anlamda kendileri hakkındaki değerlendirmeleri de belirlenmeye çalışılmıştır.

\section{Kreşin Gözüyle Kreşinler}

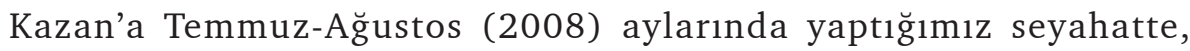
kütüphanelerde ve arşivlerde Kreşinlerle ilgili yazılı kaynakları toplarken, onları yerinde görmeyi, bugünkü durumlarını tespit etmeyi de ihmal etmedik. $\mathrm{Bu}$ amaçla Kreşinlerin önde gelenleri ile görüşmeye gayret ettik. Görüşmelerimizden birini Kreşinlerin Kazan'daki tek Kilisesi olan, Eski Tatar Bistesi'nde (Mahallesi) yer alan Tikhvin Kilisesinin papazı ve Kreşinlerin önde gelen dini lideri Pavel Pavlov (1957) ile gerçekleştirdik. Dört kız, dört oğlan olmak üzere toplam sekiz çocuk babası olan Pavel Pavlov'a Kreşinler kendi 
dillerinde "Paval Ati" (Pavel Baba) diyorlar. Pavel Pavlov, Moskova'da Duhovnıy Semineri'nde ve Duhovnıy Akademi'de öğrenim görmüş. Günümüzde Kazan'da da Duhovnıy Semineri açılmış, öğrenim görmek isteyenler orada okuyabilmekteler. Konuşmalarımızda anlaşılmayan bir şey olmasın diye Türkiye Türkçesini bilen Kazan Devlet Üniversitesi Dil ve Edebiyat Fakültesi öğrencisi İlnur'u çevirmen olarak yanımıza aldık. Kiliseyi ziyaretimizde (07.07.2008) Paval Ati'yi Elabuga'dan kendisini ziyarete gelen Kreşin papazlarla birlikte bulduk. Kara cübbelerinin içinde, uzun sakalları, kıyafetleri ve dini aksesuraları ile Kreşin Papazları Rus Ortodoks Papazlardan ayırmak mümkün değildi. Kreşinlerin günümüzdeki durumunu öğrenmek amacıyla kendisine bazı sorular yönelttik. Paval Ati sorularımıza Tatar Türkçesinde cevap verdi ve konuşmalarından anlayamadığımız hemen hiçbir şey olmadı...

Paval Ati'ye Kreşinler kimlerdir? diye soruyoruz. Aldığımız cevap, bizi şaşırtmakla birlikte bir Kreşin Papazın kendi ağzından Kreşinler hakkındaki değerlendirmeleri öğrenmeye başlıyoruz: "Biz kendimizi Tatarlardan ayrı bir millet olarak kabul ediyoruz. Tatarlarla ayn zamanda İslam dininde bulunmayan bir halkız. Tataristan'in yerli halkıyı. Astrlardir Ortodoks Huristiyanız. Resmi rakamlara göre sayımız 25 bin civarında. Ama gerçek sayımız milyonu aştı. Kazan dışında da birçok yerde Kreşin var. Zay, Pitraç, Çall, Elabuga, Kozmoyevski rayonlarında, Balık bistesinde, Mari, Udmurt, Mordvin Cumhuriyetlerinde de az ya da çok Kreşinler var. Buralarda onların kendi köyleri var. Tataristan'da 250-300 civarında Kreşin köyü var. Ancak bu köylerin çok azında kilise var."

Paval Ati'ye Kilise müdavimi cemaatinin sayısını soruyoruz. "Devam edenlerin sayısı her zaman bir olmuyor. Genellikle 100, 200, 300 kişi oluyor. Gençlerden, çok olmasa da Kiliseye gelenler var. Onların kebinlerini (nikah) kilisede yapıyoruz. Yakınlarda yaşayan Ruslardan da kilisemize bazen gelenler oluyor." cevabinı alıyoruz.

Asırlardır aynı coğrafyada yaşadıklarına vurgu yaparak Kreşinlerle diğer Tatarlar arasındaki kültürel ortaklıkları merak ediyoruz. Paval Ati bu konuda ortaklıklardan pek söz etmek istemiyor. Din dışında Kreşinlerle Müslüman Tatarların kültüründe, günlük yaşamında farklılıklar var mı? sorumuza ise Paval Ati şöyle cevap veriyor: "Evet, var. Her yönden Kreşinlerle Tatarların kültürü arasında farklılıklar var. Kültür, günlük yaşam, yemekler, ev inşası, nikah / kebin (Kreşinlerde) gibi birçok hususta farklılıklar var. Tatar mezarlıkları ayrıdır, Kreşinlerinki ayrıdır. Dil bakımından da farklılıklarımız var. Kreşinle konuşsanız Tatarların konuşmasından farklı olduğunu görürsünüz. Ama günümüzde Kreşinlerin ayrı okulları olmadığından ve Kreşinlerin de Tatar okullarında öğrenim görmesinden dolayı dilde birleşiyoruz.” 
Kreşinlerin İslam'la irtibatı var mı? Kreşinler arasında hali hazırda İslam dinine girenler oluyor mu? diye sorduğumuzda: "Bu konuda bir bilgi yok, ben bu konuda bir şey bilmiyorum." diyor Paval Ati. Kreşin dilinde yayımlanan Hıristiyan literatür hakkında ise Paval Ati'den 250'ye yakın kitap olduğunu öğreniyoruz. Ayrıca Rus Ortodoks Kilisesi ile Kreşinler arasındaki bağı ve ilişkiyi öğrenmek istiyoruz. Paval Ati şunları söylüyor: "Biz de Rus Ortodoks Kilisesi bünyesinde yer alıyoruz. 20 yll kadar önce, 1989 yzlında Kreşinler arasında da dini canlanma başladı. 1992 yılında Kutsal Kitabın çevirilerini Yunanistan'da (Atina'da) Ortodoks Kilisesi bastırıp gönderdi. Biz Kreşinler olarak artık kendi yayınlarımızı kendimiz bastırtyoruz. Kutsal Kitap gerekiyor. Başka yayınlar da gerekiyor. Paramız olduğunda şimdilerde Tataristan'da da bastırabiliyoruz kitaplarımızı."

Kreşinlere Tataristan devlet olarak nasıl bakıyor? diyoruz. Aldığımız cevap çok kısa: "Din-devlet ayrılığı var ülkede. Ama ilişkiler iyi. Herkese nasılsa bize de öyle bakıyor." Birkaç resim çekiyoruz, Pavel Pavlov'un telefonunu alıyoruz ve daha sonra bir daha görüşmek üzere Tikhvin Kilisesinden ayrilıyoruz.

Şahsi kütüphanesinden yararlanmak, Kreşinlerin kilise içindeki ibadetlerini ve cemaati gözlemlemek amacıyla Pavel Ati'nin kendisinden randevu istiyoruz. Ancak onun, Moskova'ya gittiğini ve Cuma günü (18.07.08) döneceğini öğreniyoruz. Yılda en az iki kez Moskova'da merkezi bir manastırda toplantılara katılmaları gerektiğini daha sonra Paval Ati'nin kendisinden öğreniyoruz. Cumartesi günü 19.07.08 tarihine randevuyu alıyoruz. Bu tarihte ikinci kez Tikhvin Kilisesini ve Paval Ati'yi ziyaret ediyoruz. İbadet sabah erken bir saatte başlıyor. Biz 07:30'da kiliseye giriyoruz. Kilisede Kreşinler kendi dilinde (Tatar Türkçesinde) dualar okuyor. Kilisede hemen hemen tamamı yaşlı kadınlardan oluşan 15-20 kadın cemaat bulunuyor. Dualar bittikten sonra Pavel Ati, cemaate bazı nasihatlarda bulunuyor. Kilisede bulunduğumuz sırada iki Kreşin ailenin 2-3 yaşlarındaki çocuklarını vaftiz ettirmek için geldiklerine şahit oluyoruz. Gelmişken onların vaftiz törenini de görmek ve görüntülemek istiyoruz. Paval Ati buna izin veriyor ve Kreşinlerin vaftiz törenine katılıyoruz. Paval Ati'ye bugünlerde nikah törenlerinin olup olmadığını soruyoruz. "Daha çok nikah için sonbaharda güz işlerinin bitiminden sonra köylerden gelenler olur." cevabını alıyoruz. Daha sonra Paval Ati'nin kütüphanesinde bazı kaynaklara bakıp ayrilıyoruz.

Kreşinlerin günümüzdeki durumunu öğrenebilmek için doğru kişilerle irtibat kurmaya çalıştık. Bu bağlamda Dil, Edebiyat ve Sanat Enstitüsünde Gennadi Makarov (1952) ile tanıştık ve bir görüşme yaptık (11.07.08). Kendisi bir Kreşin olan Gennadi Makarov birkaç kez Türkiye'de; İzmir'de, Koca- 
eli'nde ve İstanbul'da bulunmuş. Tatar öğrencilerle birlikte 23 Nisan şenliklerine katılmış, Türkiye'yi ve Türkleri çok sevdiğini söylüyor.

Gennadi Makarov'dan Kreşinleri bize anlatmasını istiyoruz ve bize şunları söylüyor: "Biz Tatarlarla birlikteyiz. Ama Kreşinler bugün ayrı bir etnik gurup gibi görülüyor. İdil Bulgar Devletinde Avraam adında bir Hiristiyan'dan söz ediliyor. Rus kaynaklarında bu konu ile ilgili bilgiler var. Kreşinlerin kökeni Bulgar Devletindeki Hiristiyanlara dayandırıliyor. Günümüzde çoğu Tatar, Kreşinlerin atalarının daha önceden Müslüman olduğunu düşünüyor ve bugün bizim İslam'a geri dönmemizi istiyorlar. Ama bu mümkün değil. Tatar milliyetçileri; 'biz bir milletiz' diyorlar. Bunlar etnik gözle bakıyorlar, bu anlayışla karşılanabilir. Biz Tatarlar birbirimizi etnik olarak anliyoruz, ama dini olarak anlamıyoruz. Tatarlarda "ümmet" anlayışı var. Müslüman Tatar din adamları Rus papazları ile birlikte oturup, yiyip içiyorlar, ama Kreşin papazları ile bir araya gelmiyorlar. Müslüman Tatar din adamları, Kreşin papazlarıyla el sıkışıp 'biz bir milletiz, ama ayrı dindeniz' demeye çekiniyorlar. Ülkemizde bildiğiniz gibi Rus nüfus çok. Müslüman din adamları halkın bir kısmının Hıristiyanlığa geçmesinden çekindikleri için Kreşinlerle yakınlaşmaktan çekiniyorlar. Tatarlar dini kültürle etnik kültürü karıştırıyorlar, bunları birbirinden ayıramıyorlar. Son yıllarda Ruslarda da, Tatarlarda da, Kreşinlerde de din öne çıktı. Ama şimdilerde her şey yerine oturuyor."

Tatarlarla Kreşinlerin ilişkileri ve Tatarlarla paylaştıkları ortaklıkların neler olduğu konusunu biraz daha açmasını istiyoruz Gennadi Makarov'dan. Aldığımız bilgiler oldukça ilginç: "Dil bakımından aslında Kreşinlerin dili ile Tatar Türkçesi arasinda büyük oranda ortaklıklar söz konusu. Kreşinler Tatarca öğrenim görüyorlar. Kreşin dili bugün Kilisede kullanılıyor. Kreşin dilinin "ağız"ları da var. Kreşinlerle Tatarlar arasında kültürel açıdan da ortaklıklar çok. Ama Kreşinlerin geleneksel kültürü kısmen Tatarlardan farklıdır. Kreşinler muhafazakar bir halktır. Eski geleneklerini korurlar. Tatarların çoğu eski geleneklerini unuttular. Kreşinlerde gelenekler Tatarlara göre daha güçlüdür. Örneğin; yağmur yă̆madı̆̆ında biz Kreşinler 'yağmur duası'na çıkarız. Tatarlarla Kreşinler arasında "Kız urlavu" (kız kaçırma) şeklindeki evlilik türü ortaklıklardan biridir. Tatarlar evliliğe 'nikah' Kreşinler ise 'kebin' derler.

Kreşinler çocuklarına daha çok dini mahiyeti olan Rusça, Grekçe adlar verirler. Ancak bu adlar Kreşin fonetiğine uyarlanarak söylenir. Örneğin; Aleksandır - Sandır, Varvara- Barbara, Pavel - Paval, Tatyana - Tatty, Tatuk gibi.

Ruslarla aynı dini paylaştığımızdan Rus ve Kreşin mezarlıkları ortaktır. Yalnız kırsal kesimdeki Kreşinlerin mezarı ile Ruslarınki arasında küçük bir fark vardır. Mezar üzerine dikilen haçın alt kısmına Kreşinler soy damgalarını işlerler. Bu işaretler daha çok köy mezarlıklarında görülür." 
Gennadi Makarov Kreşinlerin inanışlarından, geleneklerinden ve uygulamalarından örnekler veriyor: "Çocuğu olup ardı ardına ölen ailelerin çocuklarının yaşaması için yapa geldikleri bir uygulama var; yeni doğan çocuğu yakınlarından biri alıp sokağa çıkar ve 'çocuk buldum, satıyorum.' diyerek, çocuğu aileye para karşılığında satar. Aslında bir örtmece olan bu uygulama sonucunda Kreşinler çocuğa, erkek ise Satı, kız ise Satukay adını verirler." Çocuklara ad verilirken dikkat edilen bir başka uygulamanın daha olduğunu; çocuğun yüzünde ya da herhangi bir yerinde dikkat çeken bir 'ben' (Tatar Türkçesinde 'min') varsa, ona Minkay, Minkeş, Mintemir gibi adlar verildiğini öğreniyoruz Gennadi Makarov'dan. Ayrıca Makarov'dan Kreşinler arasında yaygın olarak kullanılan dini terminolojiden örnekler vermesini istiyoruz: "Kreşinler arasinda; Ya Rabbi, Tengri, Alla, HudayKuday, Allaga / Hudayga şükür (Allah'a şükür), aram tamak (haram yiyecek), oçtomak, oçmakh (cennet), tamug (cehennem), jazık, qonaka (günah), tın, can (ruh), Alla saklasin (Allah korusun), Huday bersin (İnşallah), aluya (evliya), uraza (oruç), avız açuu (iftar) gibi terimlerin kullanıldığını görürsünüz" diyor Makarov.

Makarov'a Tatar-Kreşin ilişkilerinin bir başka boyutunu; karşıllıklı evlilikler olup olmadığını soruyoruz. Cevap olarak: "Günümüzde Tatarlarla Kreşinler arasındaki ilişkilerde sorunlar olmasına rağmen Tatarlarla ilişkilerimiz her düzeyde devam ediyor; kız alıp veriyoruz. Genellikle Tatarlara verilen kız Müslüman oluyor, Kreşinlere gelen kız ise Kreşin oluyor. Karışık evlilikler var. Mesela; benim eşim Müslüman, Başkurt. Adı Fenise. Üç çocuğum var; Anna, Irina ve Timotiy. Timotiy oğlumun vaftiz ad, pasaportunda Timur olarak yazllıdır. Biz Sovyet zamanında gizli gizli vaftiz olduk. Eşim Fenise ise vaftiz olmadı. Vaftiz olup olmamay kendisine brraktım, o da vaftiz olmamay tercih etti. Fakat çocuklarımızı vaftiz ettirdik. Eşim buna rıza gösterdi."

Biraz da Kreşinlerin kültür yaşamı hakkında bizi bilgilendirmesini istiyoruz Makarov'dan ve şu bilgileri öğreniyoruz: "Kazan'da Kreşinlerin yoğunlaşttğ belli bir yer yok, dağılmış durumdalar. Eskiden Arçakırı denilen meydanda Kreşinlerin Merkez Okulu vardl. 1917 yzlina kadar Kreşin dilinde 250 kadar kitap basıldı̆̆ını biliyoruz. Bu kitapları derli toplu olarak bir yerde bulmak çok zor. Bugün Kreşin dilinde çıkan yeni kitaplar ise din kitapları ile bir iki şiir kitabı dışında oldukça azdır."

Son olarak söylemek istediği bir şey olup olmadığını soruyoruz Makarov'a ve o sözlerini şöyle tamamlıyor: "Biz Türklüğümüzü koruyoruz. Gagauzlar gibi farklı dinde olan Türk gurupları var. Biz de o guruplardan biriyiz. Bildiğiniz gibi dinlerin hepsi de iyiliği hedefler. Bizi de böyle kabul ediniz. Huday bizi Türk dünyasindan ayırmasın." 
Kreşinler hakkında birinci elden bilgi alabildiğimiz diğer kaynak kişi; bir Kreşin Gazetesi olan Tuganaylar'ın baş redaktörü ve Kreşinlerin önde gelenlerinden biri olan Ludmila Belausova'dır. 1960 doğumlu ve Tatar Filolojisi mezunu olan Ludmila Hanım, mezuniyet sonrasında üç yıl kadar öğretmen olarak görev yapmış; Rus okullarında Tatar Edebiyatı ve Filolojisi okutmuştur. Daha sonra kısa bir süre Çallı'da Enstitü de okutman olarak görevini sürdürmüştür. Uzun bir süredir Tuganaylar Gazetesinin baş redaktörlüğü yanında, Tat-Medya Aksiyoner Cemiyeti Tuganaylar Şubesi Müdürlügüu ile Tataristan Cumhuriyeti Kreşinleri İctimai Uyuşmasının Baş Koordinatörlügü görevlerini de üstlenmiştir.

Ludmila Hanımla röportajımızı Kreşinler başta olmak üzere Tataristan'da bulunan bütün etnik guruplara ait temsilciliklerin yer aldığı Dostluk Evi (Dom Drujba) olarak isimlendirilen binadaki bürolarında gerçekleştiriyoruz.

Paval Ati ve Genadi Makarov'a sorduğumuz bazı soruları Ludmila Belausova'ya da sorarak onun vereceği cevapları öğrenmek istiyoruz. Ona da Kreşinler kimlerdir? Sorusunu yöneltiyoruz. Aldığımız cevap öncekiler gibi ilginç: "Türk halklarından biridir. Kökleri çok eskilere dayanan, kendi kültür geleneklerini koruyan bir Türk halkıdır. Uzun yıllar Sovyetler Birliği zamanında her halkın kimliğini yok etmeye yönelik politikalar oldu biliyorsunuz. Bu politikalar Kreşinlerin, Kreşin olma özelliklerini yok edememiştir." diyor Belausova.

Tatarlarla kültürel ortaklıklarının neler olduğu, farklılıkların olup olmadığı şeklindeki sorumuza ise aldığımız cevap şöyle: "Uzun yıllar, asırlar boyunca birlikte yaşadığımı için birçok ortaklıklarımız var. Uzun yıllar Tatar okullarının eğitim sisteminde okuduk. Karşılıklı evlilikler var. Aslında Ruslarla da ortaklıklarımız var, ayrılıklar; dinde, kültürde. Biz aynı devlet içinde, aynı coğrafyada Tataristan'da yaşıyoruz. Onun için bizi Tatarlardan ayrı olarak düşünmek çok zor, karşılıklı ilişsilerimiz çok yoğun. Bazı bilim adamları eskiden bizim Müslüman olduğumuzu, İvan Grozni’nin 16. Yüzyılda Kazan'ı almasından sonra Hiristiyan olduğumuzu söylüyorlar. Aslında, belki de durum böyle. Ancak bu konuda çok sağllklı araştırmalar yok. Biz 500 yıldır Kreşin olarak yaşadıysak, bu hiç de kısa bir zaman değil. Hiristiyanlık bu zaman içinde bizim kültürümüzü, geleneklerimizi etkiledi. Çünkü manevi değerler hayatımıza yön verdi. Bu süreçte Kreşinlere özgü mentalite, gelenekler ve bir yaşam tarzı gelişti. Ama yine de biz Tatarlarla birlikteyiz, bir arada yaşıyoruz ve çok sıkı ilişkilerimiz var Tatarlarla."

Ludmila Hanım, Kreşin-Tatar ilişkisini aydınlatacak bilgiler almak için yönelttiğimiz; Tatarlar sizi nasıl görüyor, size bakışları, sizinle ilişkileri nasıl? şeklindeki sorumuza ise şu cevabı veriyor: "Tatarlarla ilişkilerimizde bir 
sorunumuz yok. Halk arasında dostluk çok iyi. Asırlardır birlikte yaşayan TatarKreşin köyleri var, karışık aileler, köyler çok. Mesela; Zey rayonunda Ahmet ayılı (köyü) var. Tatar-Kreşin köyüdür ve uzun yıllar birlikte yaşıyorlar. Bu köyde Tatar bayramları birlikte kutlanır, Kreşin bayramları da birlikte kutlanır. Eskiden bu köyde cami de, kilise de vardı. Bugün yalnızca cami var, kilise yok. Yanlış anlaşılmasın, kilisenin yapılmasında bir problem yok, ama bu yönde bir insiyatif yok, yapmiyorlar."

Kreşin-Tatar ilişkisini ve algısını aydınlatmak için sorduğumuz Kreşin Tatarı demek yanlış mı? şeklindeki sorumuza ise Ludmila Hanımdan ilginç bir değerlendirme alıyoruz: "Bizde Tatar sözü 'dini' de kapsar. Kreşin Tatarı dediğinizde Müslüman Kreşin anlaşılır. Onun için yanlış olur. Bizim kültürümüz, geleneklerimiz, ayinlerimiz Kreşinlere özgüdür. Bizim gelenek ve göreneklerimiz Tatarlara göre çok daha zengindir. Biz eski geleneklerimizi Tatarlardan daha iyi koruduk."

Kreşinlerle Tatarlar arasındaki ilişki ve birbirlerine bakışları hakkında az çok bir bilgi elde ettikten sonra buna ek olarak onların Ruslarla ortak bir inancı, Hıristiyanlığı paylaşıyor olmalarını göz önünde bulundurarak Ludmila Hanım'dan Kreşinlerle Rus ilişkilerini değerlendirmesini istiyoruz. "Kreşin köylerinde eskiden genellikle Rusça bilmezlerdi ve Kreşinlerin yaşadığ Rus köylerinde Kreşinler kiliselere gitmezlerdi. Çünkü kilisede bir şey anlamazlardı. Bu tür köylerde Kreşinler genellikle kendi içlerinden birini yetiştirip, Huristiyan geleneklerini kendi aralarında gerçekleştirirlerdi. Kreşinlerle Rusların dini bir olsa da karşıllklı evlilikler, gidip gelmeler yok denecek kadar azdl. Ancak günümüzde birçok Kreşin kendisini Ruslara daha yakın hissediyor. Çünkü artık Rusça bilmeyen kalmadı, ilişkiler daha sıklaştı. Genel olarak şunu söyleyebiliriz; kültürel açıdan Kreşin köyleri Tatarlardan da Ruslardan da ayrılmaktadır. Tatarlar arasında yaygin olan şu söz bizi anlatmaya yeter sanırım: "Tatardan kitgen, Rusga bartp citmegen." (Tatarlardan ayrılan, ancak Ruslara ulaşamayan, ya da Ruslaşamayan.) Bu sözün ifade ettiği bir etnik gurup olarak görüyoruz kendimizi.

Bugün biz Tatarlara daha yakını. Biz, Rusya Federasyonu'nda Tataristan Özerk Cumhuriyetinde yaşlyoruz. Kreşinler olarak Ruslardan da Tatarlardan da anlayış bekliyoruz. Biz her iki gurupla da anlaşlyoruz. Her iki gurup da büyük, köklü geçmişi ve tarihi olan bir halk. Ancak biz de kendimizi onlara eşit olarak görmek istiyoruz. Son yzllarda Tataristan hükümeti bizim problemlerimizle ilgilenmeye, sorunlarımızı çözmeye başladı. Bu bizi memnun ediyor."

Kreşin-Rus ilişkisi yanında Rus Ortodoks Kilisesinin Kreşinler üzerindeki rolü ve Kreşinlere ilgisi de merak ettiğimiz bir soru. Ludmila Hanımdan aldı̆̆ımız cevap ise şöyle: "Eskiden Kreşinler üzerinde Kilisenin rolü büyüktü. Rus Orto- 
doks kiliseleri eğitim alanında büyük rol oynadılar. Kilise ve kurumları hem dini hem kültürel hem de eğitim açısından Kreşinleri etkiledi. Kreşinlerin kiliseleri ve ayrı idareleri vardı. 70 yıllık Sovyet idaresi yalnızca Kreşinleri değil Rusları da Tatarları da dinsizleştirdi. Bugün Kreşin köylerinde kiliseler yapılıyor, açıllyor. Ama kiliselerde ayinleri yönetecek ve yürütecek genç papazlarımız yok. Bu gençlerimizin dine karşı ilgisizliğiyle açıklanabilir. Kreşin köyleri için ayrı papazlar hazırlantyor. Rus kiliseleri için hazırlanan papazlardan Kreşin kiliselerine görev için giden olmuyor. Kilise köylünün ve cemaatin yardımıyla ayakta duruyor. Köyde yaşayan insanlarsa az, kiliselere giden insan sayısı da az. Bunun için papazların işi zor. Genel olarak baktı̆̆ımızda SSCB döneminde kilisesi olan köyler bugün de güçlü. Ancak bu tür köyler Cumhuriyetin tamamında 4-5 tanedir. Diğer birçok köy için papaz bulunmuyor. Mesela bir Kreşin köyü olan Tüben Kama rayonu Kuşay köyünde çok güzel bir kilise yapıldı. Kazan yakınlarında biliyorsunuz Raifskiy Manastır var. Bu manastırdan bu köye iki Rus papaz (manah) getirdiler. Bu iki papaz halkla iç içe yaşıyor ve Kreşin dilini öğreniyor. Manastır ise bunların geçimini üstlenmiş durumda.

Genel olarak Kreşin köylerinde yavaş yavaş kiliseler ve çasovniler (küçük kilise) açılıyor. Kreşinler arasında kiliselerin rolü oldukça büyük. Kazan'daki Tikhvin Kilisesinde görev yapan Paval Ati'nin rolü büyük. Yeni Ahid’i yayınladılar. Diğer dini literatürü yayınlamaya gayret ediyorlar. Kazan Piskoposluğu Kreşinleri destekliyor. Kazan Piskoposu Anastasiy Afanasyev önemli Kreşin bayramlarında kiliseye gelir, Kreşinlerin kendi dillerinde dualar okur ve her zaman bizi destekler. Bizim Tikhvin kilisesinin iki önemli bayramı vardır. Biri 23 Aralık'ta, diğeri ise 9 Temmuz'da. Her kilisenin kendi bayramlart vardır. Bu iki bayramda Anastasiy bizim kilisemize gelir ve Kreşin papazlar ile birlikte dualar okur."

Avrupa'dan ve diğer ülkelerden gelen Hıristiyan misyonerlerin Kreşinler üzerinde çalışıp çalışmadıklarını, onlarla irtibatlarının olup olmadığını sorduğumuzda ise Ludmila hanımın verdiği cevap çok ilginç: "Biz, kendi halkımı için birer misyoneriz. Bizim kendimizin misyonu var. Yabancı ülkelerden gelen misyonerler genellikle Tatarlarla çalışıor. Tatarlardan Katolik olanlar da var, Protestan olanlar da var. Misyonerler genellikle bize gelmiyorlar."

Kreşinlerin kendilerini ifade edebildikleri basın-yayın organları var mı? sorumuza ise bir gazeteci olarak Ludmila hanım şunları söylüyor: "Tuganaylar adlı bir gazetemiz var. Zaman zaman diğer gazetelerde de bilgiler çık-yor. Daha önceleri Tataristan Devlet Radyosunda "Aruumusuz Kreşin Karındaşlar" adında bir program vardı. Bugün Tataristan Devlet Radyosu Rusya Federasyonu Radyosu'nun bir şubesi oldu ve bizim program kaldırıldı. Yeni yapılanmada vakti de, programı da kestiler." 
Bir Rusla evli olan Ludmila Hanım sorularımıza samimi ve içten cevaplar veriyor. Kreşinlerde Ruslaşma var mı? sorumuza da aynı içtenlik ve samimiyetle cevap alıyoruz: "Şehirde yaşayan Kreşinler Ruslaşıyor, köylerde yaşayanlar kimliklerini koruyor. Bizim isimlerimiz, kimlik bilgilerimiz hep Rusça. Şehir şartlarında bizi Ruslardan ayıran hiçbir şey yok. Şehirde Rusça konuşmamı gerekiyor. Aslında benim de Ruslaşmam mümkün idi. Ama ben Ruslaşmayı kendi adıma iyi görmedim. Sayım sırasında da ${ }^{4}$ çoğu Kreşin Rus olarak kayıtlara geçti. Prensipleri olanlar, bilinçli olan Kreşinler kendilerini Kreşin olarak kaydettirdi.

Eskiden Rus-Kreşin karışık köyler vardı. Buralarda yaşayanlar Ruslaştılar. Ama Kreşinlerle Tatarların karışık olarak yaşadığı köylerde Kreşinler kendi kimliklerini korudular. Kreşinlerin sayıca çok Rusların az olduğu köylerde, Ruslaştırma gerçekleştirilemediğinden Ruslar göçtüler. Ruslar soğuk insanlardı, Kreşinler ise oldukça sıcak kanlı kimselerdi. Benim babam Kreşin, annem Rus, ama Kreşin köyünde yaşıyorduk."

Kreşinlerin, Ruslarla ve Müslüman Tatarlarla ilişkilerinin boyutunu daha iyi göstereceği düşüncesiyle Ludmila Hanıma şu soruyu da yöneltiyoruz: Kreşinlerin Ruslarla ve Tatarlarla karışık evlikleri var. Bu iki gurup arasında gerçekleşen evliliklerle ilgili belli bir oran verebilir misiniz?

"Kreşinlerin Ruslarla evlilikleri azdır. Daha çok Tatarlarla karışık evlikler gerçekleşmiştir. Genellikle Rusla evlenen Kreşin kızı Ruslaşır. Tatarla evlenen Kreşin kızı da Tatarlaşır. Bu durum ailelere göre de değişebiliyor. Daha önce hiç kafa yormamıştım bu konuda ama aslında benim ailem bu coğrafyadaki Rus-Tatar-Kreşin ilişkilerini gösterecek ilginç bir örnektir: Benim eşim Rus. Bir kızım var, ismi Katya. Nüfus sayımlarında kızım kendi isteğiyle kendisini Kreşin olarakyazdırdı. Biz beş kardeşiz. Büyük ablamın eşi Kreşin. İkinci ablamın eşi Tatar-Müslüman. Ağabeyimin hanımı Tatar, ikinci ağabeyimin hanımı Kreşin. Ağabeylerimin ikisinin de çocukları Kreşindir. Büyük ablamın iki kızı var, ikisi de kendisine Kreşin diyor. İkinci ablam Müslüman Tatarla evlendi. İki oğlu bir kızı var. Kızı bir Tatarla evlendi, kendisi de Tatar (Müslüman) oldu. Oğlu Tatar kızıyla evlendi, Müslüman oldu. Bir oğlu evlenmedi, o da Müslüman oldu. Babaları geçen yıl öldü, onu Ortodoks mezarlığına gömdük. Çünkü onun annesi Kreşin idi.Vasiyeti, Kreşin geleneklerine göre gömülmekti, Kreşin adetlerine göre defnedildi.

Daha önce bir Müslüman ağabeysi öldü, onu Müslüman geleneğine göre defnettiler. Bunlar Müslüman köyünde yaşadılar ama Kreşin köyüne getirip defnettiler.

42002 yllında yapılan sayımlar kastediliyor. 
Tüben Kama'da yaşamakta olan büyük ağabeyimin hanımı Tatar, çocukları Kreşin. Annelerinin de rızastyla ikisi de vaftiz oldu ve kendilerine Kreşin diyorlar.

Küçük ağabeyimin hanımı Kreşin, çocukları da Kreşin."

Ludmila Hanımdan günümüzde Kreşinler üzerinde Tatarların etkisinin ne boyutta olduğu hakkında da bilgi istiyoruz: "Kreşinler üzerinde Tatarların tesiri her zaman çok olmuştur. Çünkü öteden beri Tatarlarla iç içe yaşıyoruz. Ruslar için biz hepimiz Tatarı. Ruslar Tatarlara nasıl baklyorlarsa bize de öyle bakmışlardır. Ancak dini açıdan Rus Ortodoks Kilisesinin tesiri daha çoktur, Tatar etkisi azdır. Kreşinler arasında yavaş yavaş aslına dönüş var. Günümüzde gençlerimiz nikah için kiliseye gidiyor, çocuklarını vaftiz için kiliseye götürüyorlar. Ölülerini papaz olmadan defneden çok az. Bizde Tatarların tesiri yok denecek kadar az. Müslümanlığa geçenlerin sayısı da çok değil."

Kreşinleri nasıl bir gelecek bekliyor, sizce? Şeklindeki sorumuza ise Ludmila Hanım şöyle cevap veriyor: "Onu Allah bilir. Biz Allah'tan iyi bir gelecek diliyoruz. Huday bizim yaptıklarımız görüyor."

Daha önce bir kez, Türk Dünyası Araştırmalar Vakfınca düzenlenen "Türk Dünyası Kadın Kurultayı" vesilesiyle Türkiye'de bulunmuş olan Ludmila Hanıma son olarak Türkiye hakkındaki düşüncelerini soruyoruz: "Türkiye'den döndüğümde Tataristan'da Azatllk Radyosu benimle bir röportaj yaptı. Sordular: Türkiye'den hangi düşüncelerle döndünüz? diye. Şöyle cevap vermiştim onlara: Ben Kreşinlerin bir Türk halkı olduğunu, Ortodoks başka Türk halkları da bulunduğunu orada öğrendim. Farklı dinlere inanıyor olsak da hepimizin de Türk halkı olduğumuzu anladım ve öğrendim. Ben Türkiye'de kendimi kendi evimde gibi hissettim. Başka Ortodoks Türklerin olduğunu da gördüm. Kendimizin de Türk halklarından birisi olduğumuzu, Kreşinlerin de Türk hakları arasında bir yerinin olduğunu, onlarla eşit olduğunu anladim.

Bizi bulduğunuz için size çok teşekkür erdim. Sizden ricam; bizi Türk dünyasında tanıtın. Kendi kimliğimizi, kültürümüzü tanıtmamıza yardımcı olun. Çünkü bizim güzel ve zengin bir kültürümüz var. Çünkü biz Türk dünyası buketinin en güzel çiçeklerinden biriyiz."

Ludmila Hanıma bize zaman ayırdığı ve verdiği bilgiler için teşekkür ediyor ve Dostluk Evinden ayrilıyoruz.

\section{Petrov (Pitrav)Bayramı}

Gennadi Makarov Kreşinleri daha yakından tanımamıza imkan sağlayacağını düşünerek bizi 12.07.08 tarihinde kutlanacak "Pitrav Bayramı"na davet ediyor. Memnuniyetle katılacağımızı söylüyoruz. Geleneksel hale gelen, her 
yıl 12 Temmuz'da kutlanan ve bu yıl sekizincisi kutlanacak olan Pitrav Bayramı, Kazan'a yaklaşık 160 km uzaklıkta Mamadış rayonunda Jöri köyünde kutlanıyor. Bize, Tataristan İctimai Uyuşması İdaresi Reisi İ.M. Egorov ve Mamadış rayonu, rayon Sovyet Reisi R.G. Kelimullin imzasıyla verilen davetiyede; Kreşinlerin geleneksel oyunlarının, yemeklerinin, şarkılarının, giyimlerinin, başta güreş olmak üzere çeşitli spor faaliyetlerinin sergileneceği belirtiliyor. Ayrıca çeşitli yerleşim birimlerinden gelen Kreşinlerin folklor ekiplerinin oyunlarının yer alacağı ifade ediliyor. Bayrama katılmak için saat 13:00'da Ostrovskiy sokağında Dostluk Evi'nin (Dom Drujba) önünden hareket edecek otobüse biniyoruz. Biniyoruz diyorum çünkü; bayrama Türkiye'den, Tatar Masalları üzerine çalışan Ege Üniversitesi Türk Dünyası Araştırmaları Enstitüsü Türk Halk Bilimi araştırma görevlilerinden Mustafa Gültekin ve yine aynı Enstitünün araştırma görevlisi ve yaklaşık 6 aydır Kazan Devlet Üniversitesi'nde Rusça öğrenmekte olan Muhammet Şen de bulunuyor.

Otobüste Kazan'dan Pitrav Bayramına gidecek olan Kreşinlerle tanışıyoruz; Kazan Kreşin Derneğinin başkanı Mariya Mikhailovna, aynı dernekte etkin faaliyetlerde bulunan Raisa Pavilovna, Emekli gazeteci Elizaveta Antonova, Medeniyet Üniversitesi Kütüphaneler Bölümünde görevli Tatyana Dunaeva ve eşi Tiyatro sanatçısı Nikolay Dunayev, Kreşinlerin ayda iki kez çıkardıkları "Tuganaylar" gazetesinin başyazarı Ludmila Belausova, Dil, Edebiyat ve Sanat Enstitüsünden Olga Biatikola, gazeteci Fokin Arkadi Vasilyeviç, emekli İlya V. Mikhailov, eşi Palina Mikhailova ve oğulları Vasiliy Mikhailov bunlardan bazıları. Otobüste Kreşinleri biraz daha yakından tanıma firsatı buluyoruz.

Bayram yeri oldukça kalabalık. Yalnızca Kreşinlerin değil Kreşin olmayan çok sayıda Tatarın da bayrama katıldığını öğreniyoruz. Saat 17:00'de başlayan Bayram, havanın yağmurlu olmasına rağmen ilginin kaybolmadan devam ettiği ve davetiyede belirtildiği gibi Kreşinlerin örf-adetlerinin, milli yemeklerinin, şarkılarının, oyunlarının, giyimlerinin sergilendiği sahnelerle ve programlarla kutlanıyor. Protokol konuşmalarının yanında açılışta bir papaz ve bir de imam bayram kutlamasında bulunuyor. Konuşmalar Kreşinlerin kendi dilinde Tatar Türkçesinde yapıllyor. Daha sonra Kreşin oyunları ve programda belirtilen etkinlikler gerçekleştiriliyor. Bayram yeri adeta bir panayır yerini andırıyor; geniş bir alana Kreşin yemeklerinin sunulduğu bölümler ve eğlence yerlerinin kurulduğu sahneler yayılmış. Bayram kutlamaları ve eğlenceler gece saat birlere kadar devam etti ve bu saatten sonra yavaş yavaş halk dağılmaya başladı. Biz de saat birden sonra aracımıza binerek Kazan'a hareket ettik. Daha sonra Pitrav Bayramının Kreşinlerin yoğun olarak yaşadığı; Çallı, Elabuge, Nijniy Kamsk, Kukmara, Zey, Pitraç, Mamadış olmak üzere yedi rayonda kutlandığını, büyük kutlamanın 
Mamadış'ta gerçekleştiğini, ayrıca bu kutlamalara devletin maddi destek sağladığını ve bunun Kreşinleri çok memnun ettiğini de öğrendik.

\section{Kazan Arskoy Ortodoks Şehir Mezarlığı}

Tataristan'da, Kreşinlerin mezarlığı ile Rusların mezarlığının ayrı olmadığından söz etmiş̧ik. Kreşin Tikhvin Kilisesi papazı Paval Pavlov, Kreşin mezarlarını görebileceğimizi söyleyerek bize Park Gorki'nin yanında bulunan Kazan Arskoy Ortodoks şehir mezarlığını ziyaret etmemizi tavsiye ediyor ve N.İ. İ'minski'nin mezarının da burada bulunduğunu ekliyor. Biz de hem Kreşinlerin hem de N.İ. İl'minski'nin mezarlarını görebilmek için 27.07.08 tarihinde mezarlığ ziyaret ediyoruz.

Mezarlık, bakımlı ve gösterişli. Mezarlıkta, farklı tiplerde mezarları görmek mümkün oluyor. Birçok kültürde olduğu gibi burada da mezar taşlarında isimler yazılı. Bazı mezar taşlarında isimlere ek olarak kişilerin hayatındaki uğraşları ya da işleri hakkında bilgilere yer verilmiş. Ayrıca mezar taşlarına ölen kimsenin resmi de konulmuş. Mezarların hemen hepsinde Rus Ortodoks haçını görmek mümkün. Mezarlıkta bize yabancı olmayan ve aşina olduğumuz isimler dikkatimizi çekiyor. Rastgele bir gezintiyle, mezarlıkta az da olsa Türk-İslam kültürüne ait isimlerin yazılı olduğu mezar taşlarını görüyoruz: Zeynep Şakirovna Enikeeva (1902-1982), Murat Raisa Grigorievna (ö.1947), Rustem Fazıloviç Biarslanov (1920-1999), Zöre Markovna Biarslanova (1892-1969), Yuri Ayazoviç Nazmiyev (1946-2006), Raisa Camalatdinova Yusupova (1927-2008), Bilsur Gabdullaeviç Gabdullayev (1936-2008) dikkatimizi çeken mezar taşlarından birkaçı. Bu isimler Tatarlara özgü isimler. Kreşinlerin isimleri ise genellikle Ruslar arasında yaygın olan isimler. Bu nedenle mezarlıkta yer alan Kreşin mezarlarını tespit etmek hiç kolay değil. Tatarlara özgü isimlerin yazılı olduğu mezarlar ise daha çok karışık evliliklerle izah ediliyor.

Gayri Rus unsurların Hıristiyanlaşması yönündeki faaliyetlere yön veren, hatta hayatını buna adayan N.İ. İl'minski'nin mezarı ise mezarlık içinde yer alan kilisenin hemen bitişiğinde bulunuyor. Mezar taşının önüne ziyaretçilerin yaktıkları mumları bırakabilmesi için bir tezgah konulmuş. Il'minski'nin mezar taşında ise şu ifadelere yer verilmiş: "Ebedi Antt! Burada, İnorodotslerin (gayri Rus unsurların) Hıristiyan öğretisiyle büyük aydınlatıcısı Nikolay İvanoviç Il'minski'nin na'şı yatmaktadır. 27 Aralık 1891 tarihinde yaşamı sona erdi."

Mezarın hemen arkasında, kilisenin duvarına bitişik olan camekanda ise Aziz Nikola'nın resmi yer alıyor. Aziz Nikola'nın elinde tuttuğu kitabenin karşılıklı iki sayfasında Rusça ve Tatarca şu ifadelere yer veriliyor: "Sizin 
aydınlığınızda kişiler önünde şöyle aydınlansın: Onlar da sizin iyi/güzel işlerinizi görerek gökteki Atanızı övsünler."

\section{Bir Kreşin Köyü: Çura}

Kreşinler hakkında daha geniş bilgi elde etmek, onların yaşamını daha yakından görmek üzere bir Kreşin Köyünü ziyaret etmek istiyoruz. Gennadi Makarov ve Ludmila Belausova ile Kukmara Rayonu'nda bir Kreşin köyü olan Çura Köyü'ne bir gezi planlıyoruz. Çura Köyü Kazan'a yaklaşı 120 km uzaklıkta bulunuyor. 09.08.2008 tarihinde cumartesi günü sabah erkenden hareket ediyoruz Çura Köyüne.

Ludmila Belausova Çura Köyüne seyahatimiz esnasında, 1999 yılında Türkiye'de Trük Dünyası Araştırmalar Vakfı'nın organize ettiği Türk Dünyası Kadınları Kurultayına katıldığını, bu seyahatte daha önce Türkiye hakkında zihninde oluşan yanlış ve olumsuz imajların yıkıldığını, Türkiye'yi yakından tanıma firsatı bulduğunu, bu vesileyle Turan Yazgan, Sevgi Erenerol ve daha birçok Türk ile dost olduklarını anlattı. Ayrıca Türkiye'den dönüşünde Turan Yazgan Hocanın kendilerini sağlıkla gidip tekrar Türkiye'ye gelmeleri dileğiyle araçlarının ardından su dökerek uğurladığını da ekledi.

Çura Köyüne vardığımızda bizi köyün girişinde, köyün sosyal tesisleri olarak fonksiyon icra eden bina önünde Andrey Nikolayeviç Afanasyev ve bir gurup Kreşin karşıladı. Andrey N. Afanasyev Çura Köy İdare heyeti başkanı. Andrey bize söz konusu bu binada toyların, bayramların, eğlencelerin, konferansların, sergilerin ve diğer sosyal faaliyetlerin gerçekleştirildiğini anlattı. Bu arada bize 2008 yılında kutladıkları Nardugan Bayramının resimlerini göstermeyi ihmal etmedi. Resimleri gösterirken Narduganın her y1l 19 Ocak'ta kutlanan bir bayram olduğunu, bayrama bütün Kreşinlerin önem verdiğini, hazırlıklar yaptıklarını ve bayramda genç yaşlı herkesin çeşitli eğlenceler düzenlediklerini de sözlerine ekleyerek, bize Nardugan Bayramına ait birkaç fotoğrafı hediye etti.

Çura köyüne komşu olarak Kiçe Çura, Porşur, Piçelavod Kreşin köylerinin de bulunduğunu ve Çura'nın bu köylerin merkezi olduğunu öğrendik. Çura köyünde 154 aile yaşamakta ve bir ilköğretim okulu bulunmakta. Köyde, yalnızca bir Rus aile yaşamakta, geri kalan ailelerin tamamı Kreşin. Köylü tarım ve hayvancılıkla uğraşmakta.

Daha sonra sabah ayinin gerçekleştirildiğini öğrendiğimiz Köy Kilisesine yöneldik. Kilisede yaklaşık 30 kadar Kreşin kadından ve birkaç küçük çocuktan oluşan cemaat ile Kilise papazının icra ettikleri ayini gözlemledik. Ayinin ve okunan ilahilerin, daha önce Kazan'da Tikhvin kilisesinde de gözlemlediğimiz gibi Tatar Türkçesinde gerçekleştirildiğini gördük. Ayin sonrasın- 
da cemaat bize ve diğer konuklara yakın ilgi gösterdi. Çura köyünün, Kilisesi bulunan nadir Kreşin köylerinden biri olduğunu öğrendik.

Kilise, köyün önde gelenlerinden, iş adamı Nikolay Nikolayeviç'in sponsorluğuyla yapılmış ve 28 Eylül 1993 tarihinde ibadete açılmış: Kilisede papaz olarak Filip Feodorov görev yapıyor. Halk, kısaca ona Filip Ati diyor. Filip Ati 1952 doğumlu, evli, biri kız olmak üzere 3 çocuk babası. Oğullarından biri de Mamadış rayonunda Urmançı Köyünde kendisi gibi papaz olarak görev yapıyormuş. Fìlip Ati Kiliseye özellikle Paskalyada büyük ilginin olduğunu söylüyor. Bununla birlikte gençlerin kiliseye ilgisiz kaldığından, kilisenin köy halkının yardımlarıyla ve desteğiyle ayakta durduğundan, din adamı olmak için istekli ve gönüllü insan bulmanın zorluklarından söz ediyor Filip Ati ve Kilisenin, Kazan'daki Tikhvin kilisesinden yardım ve yayın desteği aldığını sözlerine ekliyor.

Kilise ziyaretinden sonra köyün ilköğretim okuluna gidiyoruz. Burada Kreşinlere ait bazı etnografik malzemenin bulunduğunu öğreniyoruz. Okulun müdürü, bizi karşılayan Andrey'in ağabeyi Anton Nikolay. Bıyıklarıyla, jest ve mimikleriyle aslında tam bir Anadolu insanına benziyor Anton Nikolay. Bize kısaca okul hakkında bilgiler veriyor Anton. 1845 yılında köyde Kilise okulunun açıldığını, ancak 1930'lu yıllarda bu okulun kapatılarak yerine seküler tarzda yeni bir okul açıldığını öğreniyoruz.

Okulda görev yapan öğretmenlerden biri Galina Pavlovna, Kreşin etnografyasına büyük önem veriyor. Okulun folklor ekibini o hazırlıyor ve çalıştırıyor. Köyde etnografik malzeme olarak ne bulursa topluyor Galina Pavlovna. O, köyde bir kreşin müzesi açılmasını istiyor ve bunun için malzeme topladığını söylüyor. Bizim geleceğimizi öğrenince hemen birkaç öğrencisini arayarak okula çağırmış. Onlara geleneksel Kreşin kıyafetlerini giydirerek bize, zevkle izlediğimiz Kreşinlerin geleneksel oyunlarını sergiletti.

Köy okulundan ayrıldıktan sonra köy mezarlığını ziyaret etmek istiyoruz. Mezarlık köyün dışında bulunuyor. Mezarlığa giderken bazı inanışları da öğreniyoruz Andrey'den; Kreşinler, cenazelerini köyden mezarlığa altıdan su akan bir köprü üzerinden geçirmek suretiyle getiriyorlar. İnanışa göre; su üzerinden götürülen ölünün ruhu tekrar eski yaşadığ yakınlarını ve başkalarını rahatsız edemiyor.

Köy mezarlığında birkaç tane eski mezar taşı bulunduğunu öğreniyoruz. $\mathrm{Bu}$ taşlardan bulabildiğimiz birkaç tanesini fotoğraflıyoruz. 1908 yılında dikildiği anlaşılan, tarih ve haçtan başka diğer bilgilerin silinmiş olduğu taşlardan birinde Kreşinlerin soy tamgasının işlenmiş olduğunu görüyoruz. Diğer taşlardaki izler ya okunmuyor ya da silinmiş durumda. Mezar taşları, Kazan'da Rus Ortodoks Şehir Mezarlığında gördüklerimiz gibi gösterişli değil. 
Bazı mezar taşlarında resimler var, ama gayet mutevazı. Mezarların çoğunda Ortodoks haçı yerleştirilmiş, ancak bazı mezarlara haç konulmamış.

Mezar taşlarındaki Kreşin isimlerinin hemen hemen tamamı Rus isimleri; Anisa Vera Fedorovna (1880-1966), K. Hristina Vasil'evna (1908-1972), Il'in Grigoriy Trofimoviç (1932-1983), Kirillova Aleksandra Mikhailovna (ö.1976), Andreev İvan Mikhailoviç (1955-2007), Andreev Vyaçeslav İvaneviç (ö.1978), Vladimirova Anna Nikolaevna (1950-1973), Yakovleva İrina V., (1995-1996), Petrova Rimma Nikolaevna (1931-2007). Ancak mezar taşlarında diğer Tatarlar arasında yaygın olan isimler de gözden kaçmıyor; Azina Rehile Meglevi Kızı (1918-2003), Fedorova Asiya Şeyhetdin Kızı (19301998), Feyzullina Ferhinur Hemit Kızı (1949-1988) bu isimlerden birkaçı. $\mathrm{Bu}$ mezar taşlarında ise Ortodoks haçı konulmamış. Bunlar, muhtemelen Kreşinler ile evlenen Müslüman Tatar kadınlarına ait mezarlar. Mezarlıkta ayrıca vaftiz olmadan ölen küçük çocukların mezarlarına haç dikilmediğini, yalnızca Kreşinler arasında "kabir kazığı" adı verilen küçük bir tahta/odun parçası dikildiğini öğreniyoruz.

Mezar ziyaretinden sonra Andrey bizi Köyün ortasında yer alan "İzgi Çeşme"yegötürüyor. İzgi, Tatar Türkçesinde "kutsal" anlamına geliyor. Kreşinler Kutsal Kitap için de izgi sözünü kullanıyorlar. Çura köylüleri bu çeşmeye ayrı bir önem veriyor. Çeşmenin etrafını taş duvar ile çevirmişler, duvar üzerine demir parmaklıklar çekmişler, çeşmenin üzerini çatı ile kaplamışlar ve çatının üzerine de Ortodoks haçını dikmişler. Nardugan Bayramında bu çeşmeden alınan su kutsal sayılıyor. Nardugan'da her aile bu sudan bir miktar alıyor, evine götürüyor, evinde bütün bir yıl boyunca bu sudan bulunduruyor. Bu suyun bozulmadığına inanılıyor. Bu sudan bir kaşık alarak diğer sulara atıldığında o suyun da kutsallık kazandığı kabul ediliyor. İnsan ya da köylülerin hayvanlarından biri hastalandığında bu sudan içiriyorlar ya da üzerine serpiyorlar, böylece hastanın iyi olacağına inanıyorlar. Küçük bebekler sürekli ağladığında iyileşeceği inancıyla bu su ile yüzünü yıkıyorlar ve ovuyorlar.

İzgi Çeşmenin suyunun 19 Ocak'ta Nardugan günü yapısının diğer günlerdekinden farklı olduğuna inanılıyor. Nardugan günü bu çeşmeden törenle su alınıyor ve fal bakılıyor. Su falı için çeşmeden iki genç bekar kızın suyu almaları ve bu kızların suyu aldıktan sonra arkalarına bakmadan ve konuşmadan suları getirmeleri gerekiyor. Aksi halde suyun kutsallığını kaybedeceğine inanılıyor.

Daha sonra Andrey bizi yemeğe evine davet ediyor. Ailesi ile tanışıyoruz Andrey'in. Anne-babası ve bir çocuğu ile iki katlı güzel bir evde yaşıyor Andrey. Evin salonunda dikkatimizi ikonaların yer aldığı köşe çekiyor. Kreşin 
evlerinde genellikle böyle bir köşe bulunduğunu öğreniyoruz. Bu arada bizi Kazan'dan Çura'ya getiren şoförümüz Tatar. Andrey ile şoförümüz arasında geçen konuşma Kreşinlerin diğer Tatarlarca nasıl görüldüğünü göstermesi bakımından dikkate değer. Andrey soruyor şoförümüze:

- "Sen de mi Kreşinsin?"

Şoförün verdiği cevap ise ilginç ve ilginç olduğu kadar da düşündürücü:

- "Hayır, ben çistiy (saf) Tatarım".

Yemekten sonra vedalaşıyoruz ve Çura'dan ayrilıyoruz.

Sonuç

Kaynakların çoğunda Hıristiyan Tatar gurubu olduğuna dikkat çekilen Kreşinler'in çoğunluğu Tataristan'da yaşamakta, Tatar Türkçesinde konuşmakta, geleneksel kültürlerini muhafaza etmektedirler. Sayıları hakkında sağlıklı bir rakam verilememekle birlikte Rusya Bilimler Akademisi Etnoloji ve Antropoloji Enstitüsü onların sayısını 300000 olarak göstermektedir. Rusların 16. yüzyılın ortalarında İdil-Ural bölgesini ele geçirdikleri tarihten başlayarak 20. yüzyılın başlarına kadar gayri Rus unsurlara ciddi biçimde Hıristiyanlaştırma ve Ruslaştırma politikaları uyguladıkları bilinmektedir. Bu politikalarda Hıristiyanlaştırma Ruslaştırma, Ruslaştırma da Hıristiyanlaştırma ile aynı anlamda düşünülmüştür. $\mathrm{Bu}$ politikalar sonucunda bölgedeki Fin-Ugor halkları yanında Çuvaşlardan ve Tatarlardan da Hıristiyanlaşanlar olduğu tarihi kaynaklarda ve yapılan araştırmalarda ortaya konulmuştur. Bugüne kadar Kreşinler hakkında yapılan değerlendirmeler de onların bu politikalar neticesinde Hıristiyanlaştıkları şeklindedir. Bu yüzden onlara "Hıristiyanlaşan Tatarlar" gözüyle bakılmıştır. Kreşinler, Hıristiyan oldukları için çoğu zaman Tatarlarca ihmal edilmiş, iyi birer Hıristiyan olmadıkları için de Ruslarca dışlanmıştır.

Günümüzde değişen ve yeni oluşan siyasi, tarihi ve kültürel şartlarda Kreşinler, sosyal, siyasi ve kültürel açıdan kendilerine hem yaşadıkları coğrafyada hem de bir parçası oldukları Türk dünyasında bir yer bulma çabasındadırlar. Bu çerçevede onlar kendilerini, Gagauzlar gibi Türkçe konuşan, Hıristiyan bir Türk grubu olarak görmektedirler. Tatarlardan ayrı bir etnik gurup olarak tanınmak istemekte, özellikle entelektüelleri bu yönde yapılanma gayretlerini sürdürmektedirler. Bu gayretler Rus politikacıları ve Kilise tarafından destek görmektedir. Ancak onların ayrı bir etnik gurup olarak tanınma gayretleri Tataristan'da Tatarların diğer etnik guruplar karşısında siyasal alanda güç kaybetmesine yol açmaktadır. 